\title{
Tolerance and Attitudes toward Diversity in Concrete Operational Stage Children
}

Wahyu Nurramadan Widayanto ${ }^{\mathrm{a}}$, Satria Akmal Akhmad ${ }^{\mathrm{b}}$, Femita Adelina ${ }^{\mathrm{c}}$, and Puji Rahayu $^{\mathrm{d}}$

${ }^{a}$ Faculty of Psychology, Universitas Airlangga, Surabaya, Indonesia; ${ }^{b}$ Faculty of Psychology, Universitas Airlangga, Surabaya, Indonesia; ${ }^{c}$ Faculty of Psychology, Universitas Airlangga, Surabaya, Indonesia; ${ }^{d}$ Faculty of Psychology, Universitas Airlangga, Surabaya, Indonesia;

*Corresponding author:

Wahyu Nurramadan Widayanto

Faculty of Psychology

Universitas Airlangga

Kampus B UNAIR - Jl. Airlangga 4-6

Surabaya, East Java 60286 - Indonesia

Tel.: +62 $315032770 / 5014460$

Email address: wahyu.nurramadan.widayanto-2017@psikologi.unair.ac.id 


\title{
Tolerance and Attitudes toward Diversity in Concrete Operational Stage Children
}

\begin{abstract}
Data from the Social Progress Imperative 2017 Summit show that Indonesia was ranked 117 out of 128 countries in the category of intolerance. The data show that Indonesia has a poor attitude toward diversity and implicitly shows that the younger generation must face the challenge of intolerance. To teach tolerance in schools and show youngsters how to be able to respond to differences, it is necessary to pay attention to the right developmental phase to teach them. Children in the concrete operational stage can classify objects, orders, and solve problems in a concrete and systematic way, based on what is obtained from their environment. Based on these characteristics, it is possible to teach tolerance to children in the concrete operational stage. Tolerance is considered a virtue moral, and children can respond to diversity more wisely if they have a tolerant attitude. This study aims to determine whether there was a relationship between tolerance and attitude toward difference in children in the concrete operational stage. The researchers used a purposive sampling with an accidental sampling technique. The results indicated a positive relationship between tolerance and attitude toward diversity. Tolerance is a value that is not obtained naturally but obtained through a process of socialization from family, school, and playmates. The more positive their environment was in responding to differences, the child will develop positive values for differences to be more tolerant and vice versa. The weakness of this study was the lack of control over homogeneous conditions in the population. Suggestions from this research are for schools and the elements in it to optimize programs and policies with tolerance.
\end{abstract}

Keywords: tolerance, multicultural education, concrete operational development, moral virtue

\section{Introduction}

Indonesia has thousands of different peoples, ethnicities, tribes, and religions with different customs, norms, and languages. In such a multicultural country, diversity is a form of strength that must be maintained. Bhinneka Tunggal Ika, or Unity in Diversity, is Indonesia's official motto, and there needs to be a strengthening of the unity of the Indonesian people. However, recently several issues have emerged in Indonesia. There are five of the most horrible SARA (i.e., ethnicity, religion, and race) conflicts that have ever occurred in Indonesia, such as the religious conflicts in Ambon, Trisakti 1998, Sampit tragedy, government conflict vs. separatist group conflicts (GAM), and attacks on Syi'ah group in Sampang (news.okezone.com, 2016).

These issues arise mostly due to a lack of tolerance in responding to the diversity of peoples. Data from the Social Progress Imperative 2017 Summit show that in 2014-2017, intolerance in Indonesia was on the increase. In 2014, the intolerance score stood at 27.90, and in 2015, it increased to 32.30. Then, in 2016, it decreased to 29.57 and again rose to 35.47 in 2017. This point put Indonesia at the ranking of 117 out of 128 countries in the category of intolerance. That means that Indonesians have a bad attitude toward their country's diverse population. The data show that the next generation of Indonesians must face the challenge of intolerance. 
Tolerance needs to be focused on in society, especially in the schools, to provide modeling for children in addressing differences wisely, so that they will become a virtuous generation. Bringing up children to be tolerant and to engage with the diversity, role models must pay attention to the correct developmental timing to teach them. According to Piaget, children from about 7-11 years old are in the concrete operational stage of development, characterized by organized and rational thinking. At this stage, their children's objectivity increases, and they are able to think about things in a concrete and systematic way. Based on these characteristics, children are at a good point to process information about tolerance and non-discrimination.

Tolerance affects peoples' ability to empathize with others, have self-insight, and build good moral values for oneself. It involves respect, equality, and freedom. During this developmental phase, children are able to think logically about events in the world, and they understand conversations, so they can understand diversity as well if they have tolerance attitude. The current researchers are interested in examining the relationship between tolerance and attitude toward diversity in children at the concrete operational stage of development. This research is expected to serve as the basis of making policies and programs to teach tolerance diversity so that they can coexist wisely in their environment.

\section{Theory}

\section{A. Tolerance}

Tolerance is an attitude of appreciation and honor for differences and advocating for a peaceful and harmonious life (Corneo \& Jeanne, 2009; Tillman, 2004; Galtung, 1967). Corneo and Jeanne (2009) have created a simple model, explaining the four postulates regarding the tolerance of individuals. These are (1) an evaluative attitude; misses the perception of acceptance, admiration, and something that is contrary to their characteristics and actions. (2) approbativeness; individuals want good opinions about themselves regarding other peoples. The approval environment that is relevant can be family, friends, colleagues, neighbors, or individual communities. (3) self-approbativeness; individuals have a desire to maintain or increase selfesteem. This desire is the pleasant idea of the individual to assume self-awareness, and (4) consistency; this postulate is in accordance with the rules of self-assessment because everyone has an assessment for others.

Allport (1954) conceptualized tolerance and broke it down into warm tolerance (being approving of others), cold tolerance (e.g., putting up with things we do not like) and limits of tolerance (being intolerant of intolerance in others). According to Allport, tolerance is a personal value that influences open and accepting attitude, the ability to empathize with others, self-insight, resistance to ambiguity, and build values in individuals. Butrus and Witenberg (2013) have referred to tolerance as a moral virtue equivalent to respect, equality, and freedom.

\section{B. Multicultural life}

Multiculturalism is a paradigm for maintaining harmony between ethnic groups and others (Mulyadi, 2017). Multiculturalism has two main characteristics: first, it is an idea to regulate diversity with the basic principle of recognizing diversity itself; second, it emphasizes on the 
legitimacy of cultural diversity or cultural pluralism (Suparlan, 2002). Along with the development of science and technology and the formation of a global society, it is very unfortunate if the meaning of diversity fades. The development of multiculturalism must absolutely be formed and taught in a pluralistic society (Lestari, 2015)

Every person in society has a role in helping to achieve a tolerant and harmonious society. For example, teachers who have a positive attitude toward multiculturalism can help reduce students' prejudiced attitude (Hanurawan, 1997). Thus, the attitude of discrimination against other people can be changed through education in multiculturalism. Teaching multicultural values to children can be done through formal and non-formal channels. Equality in diversity can be achieved only if the diversity that exists in Indonesia can be respected (Khuza'I, 2001).

\section{Child Development at the Concrete Operational Stage}

According to Piaget, child development is divided the sensory-motor stage (0-2 years), preoperational stage (2-7 years), the concrete operational stage (7-11 years), and the formal operational stage (11-15 years). Children aged 7-11 years old, children's in-depth thinking increases, their logic increases, and their objective thinking increases. They start to be able to classify objects, put things in order, and solve problems in concrete and systematic ways based on what is they have learned from their environment. During the concrete operational stage, children become more rational and they begin to explore objects and solve problems. Additionally, at this developmental stage, children begin to make critical judgments about people and situations. (Santrock, 2007). Furthermore, at this stage, children have begun to understand conversations with other people and they develop the ability to discuss and solve problems. They begin classifying objects into categories and exploring and understanding the relationship between these objects (Santrock, 2007). According to Hurlock (1980), at the concrete operational phase, children express their emotions through their behavior, and psychological and physiological factors influence their emotional expressions. Emotions in children concrete operational phase can increase or decrease at a certain age.

\section{Children in Addressing Diversity}

Without tolerance, children's characters will not be formed properly. Tolerance is one of the nine pillars of character to be cultivated in children. These include the following: (a) loving God, the universe, and its contents; (b) responsibility, discipline and independence; (c) honesty; (d) respect and courtesy, (e) affection, caring, and cooperation, (f) self-confidence, creativity, hard work; perseverance; (g) justice and leadership; (h) kindness and humility; (i) tolerance and love of peace and unity (Santrock, 2007).

\section{Research Methods}

\section{A. Research Design}

examine the status of groups, an object, a condition, a system of thought or a class of events in the present (Nazir, 2005), and correlational research is used to determine the relationships between variables. In this study, the independent variable is tolerance (X), and the dependent variable is attitude toward diversity (Y). 


\section{Population and Sample}

Population is a generalization area consisting of objects or subjects that have certain qualities and characteristics that are set by researchers to be studied (Sugiyono, 2014). The population in this study were children in the concrete operational phase. The sampling technique in this study was accidental sampling. The sample was chosen with the following characteristics:

a. Male or female students in elementary schools, the madrasah ibtida'iyah, or the equivalent.

b. Male or female students aged 7-11 years.

c. The number of samples was based on Lemeshow's formula so that the number $n$ is $96.04 \approx 97$ which means the $95 \%$ confidence level in the random sample will give an estimated difference of $x$ with, $\mu<0.05$. Therefore, to get an optimal number of samples, the researchers decided to use 100 subjects.

The selection number of samples is based on the Lameshow's formula, so that the number $n$ is $96.04 \approx 97$ which means the $95 \%$ confidence level in random sample will give an estimated difference of $x$ with $\mu$ less than 0.05 . To get optimal number of samples, the researchers decided to use 100 subjects.

\section{Research Instrument and Analysis Technique}

The research instruments used in this study were the scale of tolerance and scale of attitude toward diversity. The researchers developed these scales based on aspects of the Interpersonal Tolerance Scale $(r=0.786)$ and the Miville-Guzman Universality-Diversity Scale - Short Form $(r=0.930)$, respectively. The two research instruments used a Likert scale with four response points, from sangat setuju to sangat tidak setuju. The relationship between tolerance and attitude toward diversity was analyzed using the Pearson product-moment correlational coefficient with the help of the IBM SPSS 20.0 program.

\section{Results}

The data collected on tolerance and attitude toward diversity from 100 subjects showed three value categories--high, medium, and low. Table I shows the distribution of these categories.

Table I. Distribution of Value Categories between Variables

\begin{tabular}{|c|l|c|}
\hline \multirow{2}{*}{$\begin{array}{c}\text { Value } \\
\text { Category }\end{array}$} & Variable \\
\cline { 2 - 3 } & Tolerance (\%) & $\begin{array}{c}\text { Attitude } \\
\text { diversity (\%) }\end{array}$ \\
\hline High & 17 & 14 \\
\hline Medium & 67 & 71 \\
\hline Low & 16 & 15 \\
\hline
\end{tabular}


Table I shows that 17 subjects $(17 \%)$ are in the category of high tolerance, 67 subjects $(67 \%)$ are in the moderate tolerance category, and the remaining 16 subjects $(16 \%)$ are in the low tolerance category. Additionally, Table I how that attitude toward diversity put 14 subjects $(14 \%)$ in the high value category, 71 subjects $(71 \%)$ in the moderate value category, and 15 subjects $(15 \%)$ in the low value category.

Table II. Correlation Test Results

\begin{tabular}{|c|c|c|c|}
\hline Variable & $\boldsymbol{N}$ & $\boldsymbol{R}$ & Significance \\
\hline $\begin{array}{c}\text { Tolerance and Attitude } \\
\text { toward Diversity }\end{array}$ & 100 & 0,559 & 0,000 \\
\hline
\end{tabular}

The results of the Pearson product-moment test on tolerance level and attitude toward diversity scores was a correlation coefficient of 0.559 , with a significance level of less than 0.05 . These results indicated that the hypothesis was approved, and there was a correlation between tolerance and attitude toward diversity of children in the concrete operational development. The direction of the relationship between the two variables is marked with (+). This means that if the variable $\mathrm{X}$ (tolerance) is high, the variable Y (attitude toward diversity) will also be high.

\section{Discussion}

The levels of tolerance and attitude toward diversity of children in the concrete operational phase are mostly in the moderate category. The same degree of distribution between tolerance and attitude toward diversity in the concrete operational phase shows that these children are able to control emotional expressions (Hurlock, 1980). The results of tolerance values and attitude toward diversity showed the degree of diversity between high and low categories. For tolerance only $17 \%$ of the subjects are in the high category and $16 \%$ are in the low category, their attitude toward diversity show only $14 \%$ are in the high category and $15 \%$ are in the low category.

Hurlock (1980) has mentioned that children in the concrete operational phase have a strong desire to control their emotional expressions. Hurlock (1980) mentions that children in the concrete operational phase have a strong desire to control emotional expressions when in certain situations. When they reach school age, children begin to understand negative emotions related to social rejection by their peers. Thus, an analysis that shows the significance of the relationship between tolerance and attitude toward differences, without knowing how the children in concrete operational phase feels emotionally about tolerance and responds to diversity, becomes inappropriate. By analyzing the data on the distribution of values between the variables of tolerance and attitude toward diversity, we know that children in the concrete operational stage of development have a different tolerance and response to diversity than adults or even children in the formal operational stage do (11-15 years old).

Hurlock (1980) has mentioned that the emotions of children at the concrete operational phase depend on their physical and environmental conditions. Therefore, the condition of a child's school and its components are very important. For children in the concrete operational stage, the relationship between tolerance and attitude toward diversity cannot be separated from school 
elements such as the Thus, the role of teacher is very important to successfully inculcate multiculturalism into the lives of students. Teachers who have a positive attitude toward multiculturalism can help students reduce their prejudiced attitude (Hanurawan, 1997). Thus, in Indonesia, discrimination against other people can be brought to an end through teaching about multicultural living and peace and harmony.

According to Corneo and Jeanne (2009), an evaluative attitude is an important factor that influences tolerance levels, in children at the concrete operational stage. Hurlock (1980) has asserted that since these children have increased cognitive abilities, everything they are taught will be immediately processed. Children will have a high level of tolerance if they have been taught a good system of values. The results show that children in the concrete operational phase have significant tolerance attitude toward diversity. Most children are in the medium category. Their evaluative attitude in response to diversity is the result of their value system.

According to Corneo and Jeanne (2009), a significant relationship between tolerance and attitude toward diversity is possible because there is agreement from people in a child's environment such as teachers, family, friends, neighbors, and other members of society. Hurlock (1980) has asserted that children at the concrete operational stage express their emotions through their behavior. Therefore, if they get positive suggestions and feedback from their environment, their levels of tolerance will become stronger. However, Santrock (2007) revealed that children at this stage will actually have difficulties because they are still not cable of purely abstract thinking; therefore, this means that the teachers, parents, and other school elements become even more central to school children's development of tolerance.

Hurlock (1980) has mentioned that school aged children usually have a strong desire to control their emotional expressions, and that this is related to their newfound ability to understand their negative emotions. At this developmental stage, children are often concerned about social rejection by their peers to avoid harming their self-esteem. Corneo and Jeanne (2009) refer to the desire to maintain or increase self-esteem as self-approbativeness. The significant relationship between tolerance and attitude toward diversity for children in the concrete operational stage can be interpreted as an indication of their ability to evaluate themselves positively.

In the concrete operational phase, children become increasingly able to judge themselves and evaluate the value of others. This situation is referred to as consistency by Corneo and Jeanne (2009). The significant relationship between tolerance and attitude toward diversity shows that these do not tend to manipulate their self-image in the way adults do.

Another factor that influences the relationship between tolerance and attitude toward diversity in children at the concrete operational stage is that they begin to have the ability to think logically on events around them and are able to understand conversations and solve problems (Santrock, 2007). In this way, tolerance becomes part of their value system the process of. The more positive their environment is toward diversity, more the likely that children will develop positive values for difference and become more tolerant overall. 


\section{Conclusion}

The results of this study assigned three levels of tolerance for children in the concrete operational stage of development. Most children at this stage had tolerance levels and attitude toward diversity rated in the medium category. The results of the correlation test on both showed that there is a significant correlation between tolerance and their attitude toward diversity in children in the concrete operational phase. Tolerance is learned through the process of socialization with family, school, and playmates. The more positive their environment toward diversity, more the likely that children will develop more tolerant values and become wiser in responding to diversity. The subjects in this research were fairly homogenous with almost the same educational, social, economic and cultural background; therefore, there are likely to be differences in results if the characteristics are more controlled. Based on this research, it is recommended that schools and teachers to create more programs and policies that stress tolerance.

\section{References}

Allport, G. W. (1954). The Nature of Prejudice $25^{\text {th }}$ Anniversary Edition. Cambridge, MA: Perseus Books.

Azwar, S. (2012). Penyusunan Skala Psikologi (Edisi II). Yogyakarta, Indonesia: Pustaka Pelajar

Butrus, N. \& Witenberg, R. T. (2013). Some personality predictors of tolerance to human diversity: The roles of openness, agreeableness, and empathy. Australian Psychologist, 48(4), 290-298. doi: 10.1111/J.17429544.2012.00081X

Corneo, G. \& Jeanne, O. (2009). A Theory of Tolerance. (CESifo Working Paper No. 1941). Munich, Germany: IZA.

New.okezone.com. (2016). Lima Konflik SARA Paling Mengerikan Ini Pernah Terjadi di Indonesia. Retrieved from www.news.okezone.com.

Emzir. (2010). Metodologi Penelitian Pendidikan: Kuantitatif dan Kualitatif. Jakarta, Indonesia: Rajawali Pers.

Galtung J. (1967). Theories of Peace a Synthetic Approach to Peace Thinking. Oslo, Norway: International Peace Research Institute.

Hurlock, E. B. (1980). Psikologi Perkembangan. Jakarta, Indonesia: Erlangga.

Hanurawan, F. (1997). Sikap Guru terhadap Peran Pengajaran Kajian Multikultural dalam Mengurangi Prasangka Siswa. Jurnal Ilmu Pendidikan Agama, 4(3).

Khuza'I, R. (2001, July-September). Harmoni dalam Berbeda Demi Meningkatkan Potensi Diri. Mimbar No.3 Th. XVII.

Lestari, G. (2015). Bhinneka Tunggal Ika: Khasanah Multikultural Indonesia di Tengah Kehidupan SARA. Jurnal Pendidikan dan Kewarganegaraan, 28(1), 31-37.

Mulyadi M. (2017). Membangun NKRI dengan Multikulturalisme. Majalah Info Singkat: Kesejahteraan Sosial, IX (10).

Nazir, M. (2005). Metode Penelitian. Bogor, Indonesia: Ghalia Indonesia.

Santrock, J. W. (2007). Children (10 th ed). New York, NY: McGraw-Hill Companies Inc.

Sugiyono. (2014). Metode Penelitian Pendidikan:Pendekatan Kuantitatif, Kualitatif, dan $R \& D$. Bandung, Indonesia: Alfabeta.

Sugiyono. (2015). Metode Penelitian Kuantitatif Kualitatif. Bandung, Indonesia: Alfabeta.

Suparlan P. (2002, $16^{\text {th }}-19^{\text {th }}$ July). Menuju Masyarakat Indonesia yang Mutikultural. Keynote Address presented at the $3^{\text {rd }}$ International Symposium of Journal Antropologi Indonesia, Universitas Udayana, Denpasar, Bali.

Tillman, D. (2004). Pendidikan Nilai Untuk Kaum Muda Dewasa (Terjemahan Risa Pratono). Jakarta, Indonesia: Grasindo. 